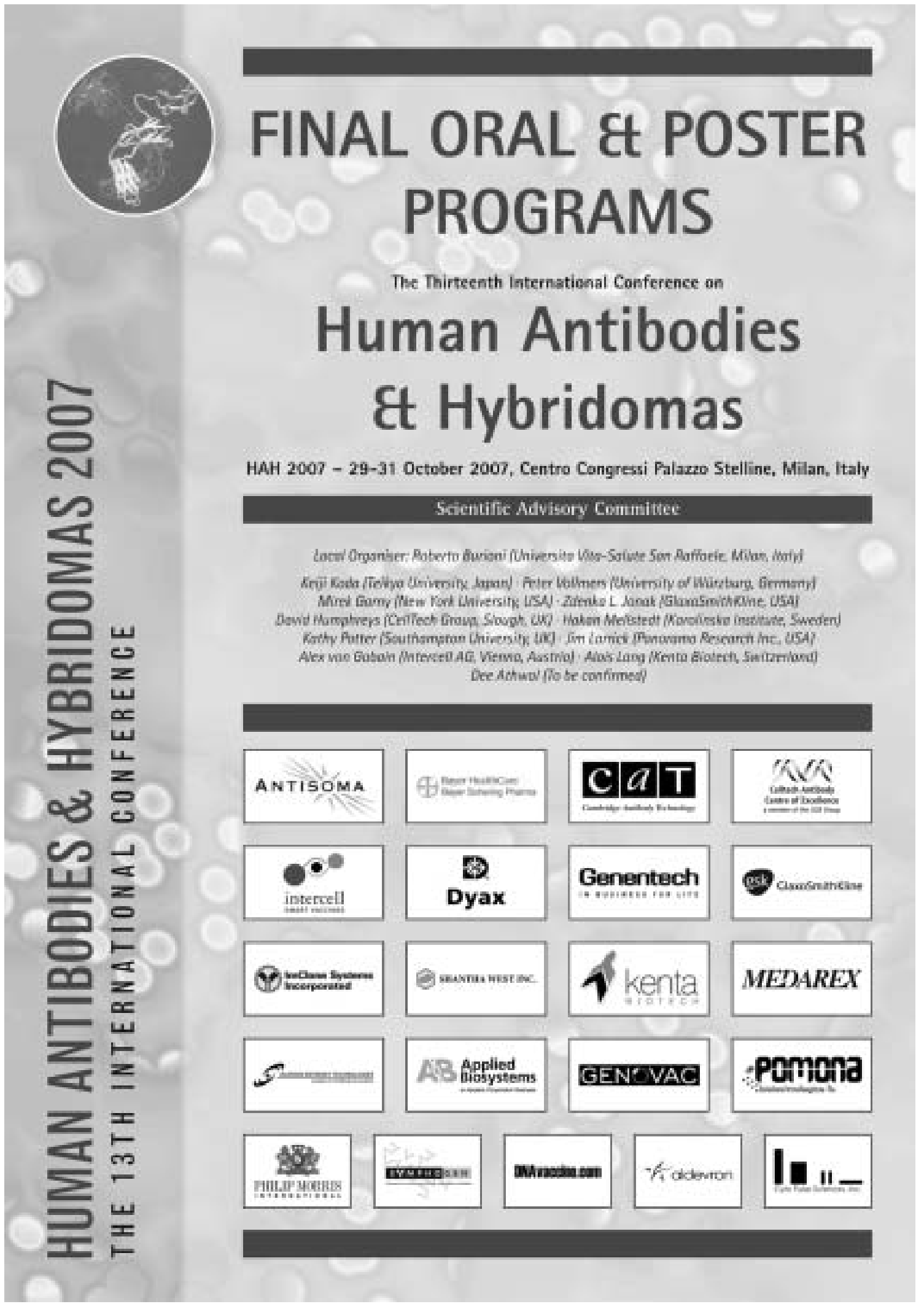




\section{SESSION 5:}

\section{ANTIBODY REPERTOIRE}

Nentrotur: Tha he curfirned

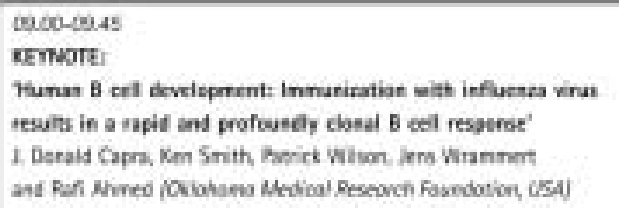

\section{9+5-1005}

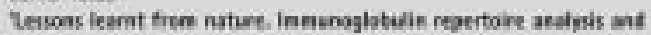
single chain Fr ambshy lasaries froes a cells in breast coccosens. and nelonuenas

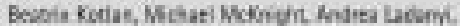

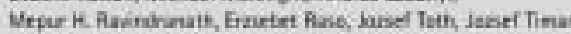

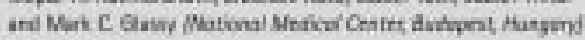
mos-1025

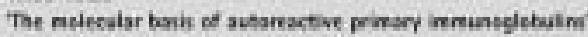
Clary B. Mclean Dontal Che and bone W. Schrider

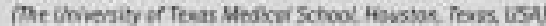

m.25-10.45

Ventificatien and characterisation of emamalagtus

innuroglobslis camtant

lanusa Arus Sengre he, USA]

m. $45-17.00$

Cother Bussk E Posies.

SESSION 6:

CANCER III

Matriaturs: To te canfinre:

\section{1).00- 1030}

Manodicnal astibodin that minic the T call merptor

and human dhrave'

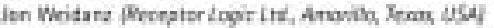

\section{7. $20-12,00$ \\ The huran antbody SWA- 6 defies a nee tumaar-specific \\ variant of the hoat wheck pratrin Carze

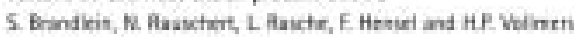 Mhiverity of Wuaturg Eensaty}

\section{$1200-1220$}

'If whes ind is whe astitums activites of anti HEFV-K antited aceinst bereast cafcer'

F. Watc-Jchinim, P. Yas, K. Fyea, IB. Furnet C. Wha ase

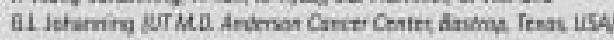

$12.201-12.40$

The 14/7, masedsnd antitedy thot medistes nen-ageptatic cetl death

Corstre Mobeo de Acosta et al

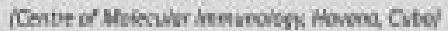

\section{$12.90-1300$}

'Anti-Ertak2 human innanazgent'

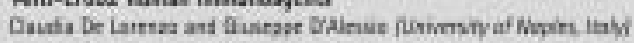

$1300-1400$

Linch $\theta$ hinirs

SESSION 7:

INFECTIOUS DISEASES I

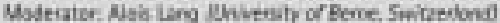

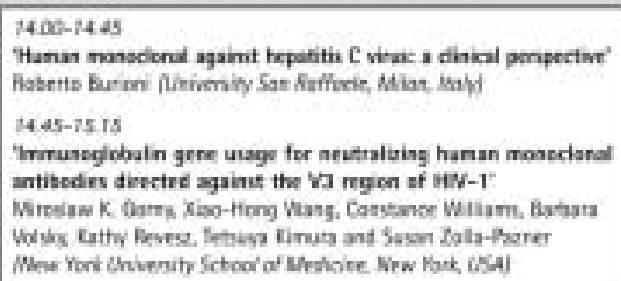

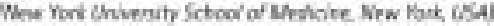

\section{$18.25-15.15$}

'Antbodiei meshatim trottetien of a and with dreet funsicidal activity a the isotppe makes a tifference' Mrasela Torosaetucci, Fove Oian, Core Bonula ont Amarin Cavare fiss, farse, thay

\subsection{5: 15.55}

The af a asvel trtern-bytridana nethad ta elone potere, hige

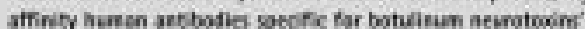

Soutr K. Deisuin, Sharat F. Adehat, R. Mas Lines, MD. Elah.

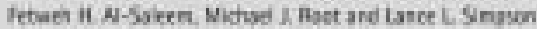

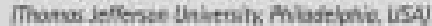

$1650-16.93$

Tea A Foith

\section{SESSION B:}

\section{MOLECULAR BIOLOGY ॥}

\section{Maderater to be vasfined}

$1030-3659$

Hibsome diplay foe aecbody ereineering'

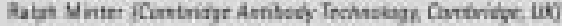

$16.50-17.00$

Teneratien of high anthety protucing N50 exll lies

oy site-seccitic recombiation

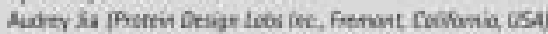

$17,20-7730$

FasMat, a fint track for selecting tigh affinty

Hack coide anthades"

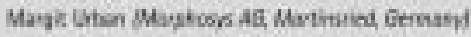

$17.10-17.50$

'Antbaty manealion dinpley spotern'

Dovid Shen fingen int USA)

1750-58.20

A rov appraach to antibety materatige strough bech deaniagtion in a rebsviral yster'

Mrien Ly, Carrth I Wilars and Mrtael S. Nesteragr

fronox lac. Hossson Tewer USN

Froning:

Conferenee Dimaer

Vhat te be canfimnt

\section{HAH 2007 Conference Secretariat, Mectings Management}

The Barn, Rake Meadow, Statian Lant, Milfard, Surrey, GUB SAD, United Kingbam Conference Malager: Caroline Sumer Teleptane: $+44(0) 1483427770$ Fox: $+44[0] 1483428516$

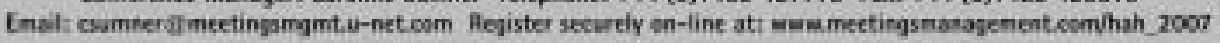




\section{Conference Program - Poster Session}

'Ma eptiwised matodengi anti-Cogo aebbod, with eshances ADOC agoinat tomer cels fice 8-CLt astienti

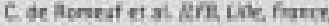

Wonsclanal anthaties in the dagnevis of ponte des potits ruminast [TW: vinu infection'

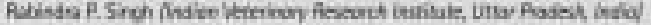

'A ghoha-eriasogratic acoaum of the setusatial marphogenesis of intridana cevelsperent'

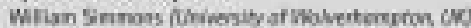

"Oleseluminesesce is a chaice method in the griwinar stajes of greering taitheart bieeds and hoteideras in the development of manedaral antisodes

Witan Sirman Rhiventy or Wefiemanptise (ix)

Canzarivas of arrun free medium and aerum rich netian it hpatitorra develupmont at whedanitolsotypite ghase and haw is. impoces on proteis purineatian Abe a dhaice methed of reducieg use of anisals in scientific eaperiments'

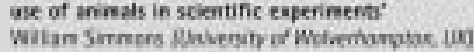

The Barn, Rake Meaderw, Station Lane, Milford, Surrey, GUB SAD, United Kingtom Conference Managers Caroline Suener Teleptane: +44 foj1483 427770 Faxi +44 (0) 1483428516

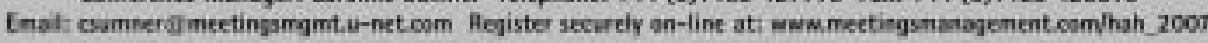


The HaH 2000 Scientific Asvisory Cammittee aed the ocganizen mould like to acknowiedge Be sugpart of the following sponscrs:
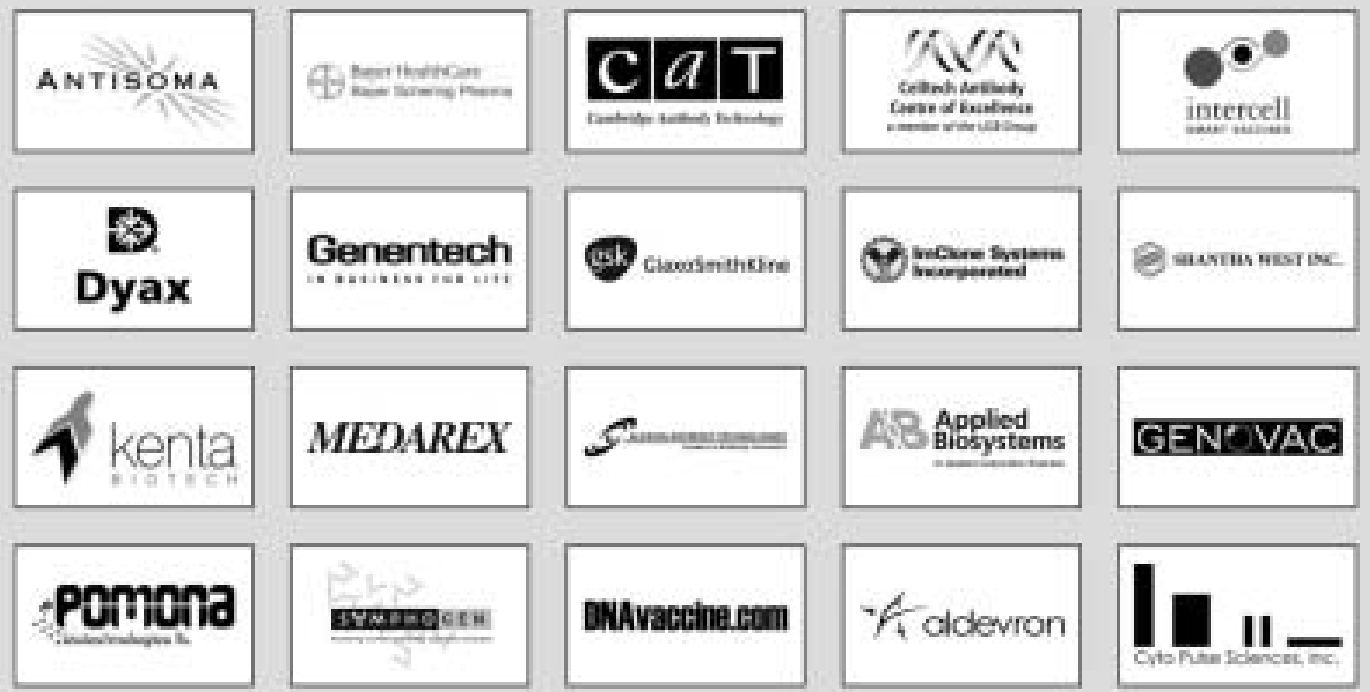

HAH 2007 Conference Secretariat, Meetings Management

The Blarn, Rake Meadow, Station Lane, Milfard, Surrey, EUB SAD, United Kirgbam Conference Manager: Careline Suener Telephane: $\$ 44(0) 1483427770$ Fax: $\$ 44(0) 1483428516$

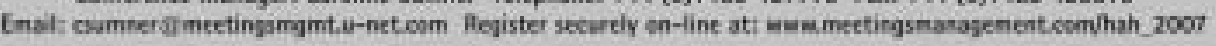

